\title{
Fruit and seed characteristics among selected Parkia biglobosa (JACQ) G. Don. Population
}

\author{
*Olorunmaiye, K.S ${ }^{1}$, Fatoba, P.O ${ }^{1}$, Adeyemi, Oreoluwa.C. ${ }^{1}$ and Olorunmaiye, P. M ${ }^{2}$ \\ ${ }^{1}$ Department of Plant Biology University of Ilorin, Nigeria \\ 2 Department of Plant Physiology and Crop Production University of Agriculture, Abeokuta, \\ Nigeria \\ *Corresponding author: ksolorunmaiye@yahoo.com \\ ABSTRACT
}

Fruit Characteristics (pod length, number of pod per bunch, pulp and seed weight, pulp weight and pod breadth), Seed Characteristics (number of seed per bunch, expected seed number per pod and seed weight per bunch), and Qualitative Characteristics of seeds (seed colour, shape, size and texture) of Parkia biglobosa (Jacq) G. Don population were investigated in this study. Twenty six (26) $P$. biglobosa population were sampled at the permanent site of the University of Ilorin, Nigeria, in May 2010 and fruits were collected from these populations for study. Pulp and seeds were removed manually from the dry brown indehiscent pods by using hand to break the pods along their sutures and de-pulping was done by manual washing with hands in water. There were significant differences (at $\mathrm{P}=0.05$ ) among the fruit and seed characteristics of 26 populations of $P$. biglobosa investigated. Five (5) plants showed high pod number per bunch with 20 pods and above while long pod lengths were observed in seventeen (17) plants. Two (2) plants have narrow pointed tip pods (apex) and four (4) plants with broad pod breadth. One (1) plant has its apex size similar to its base $(1.53 \mathrm{~cm})$. Seventeen (17) plants were observed to have more than 100 seeds per bunch while, only one plant was noticed to exhibit wrinkled seed coat, the fifteen (15) plants had flat oval seeds. Two (2) plants had pure black seed coat and twenty four (24) had brownish seed coat colours. Larger percent of the plants have medium seed size, five (5) plants have small seed size and others are of big size.

Keywords: Parkia biglobosa, pod, pulp, seed, pod length, seed weight, seed colour and seed texture.

\section{INTRODUCTION}

Parkia biglobosa (Jack.) G. Don. also known as dawadawa (Hausa), African locust beans (English), Igba/lyere (Yoruba), Nere (Bambara) have been known to be a native of Africa and is an important multipurpose tree of West African Savannah land and one of the most common species of the parkland agro-forestry system (Sacande and Clethero, 2007). More attention have been given to economically important species of tree plants especially $P$. biglobosa in recent years to a sustainable use and integrated management due to an increasing recognition of its contribution to fulfil basic needs of people, household economics, food security and conservation of natural resources (Joshi and Joshi, 2009). P. biglobosa as a common species of the parkland agro-forestry, plays important roles such as food and wood production, supply of timber, firewood, pulp and fibre through fodder, gum, drugs, and dyes as well as restoration of fertility (Okafor,1980; Popoola and Maishanu,1995). In most of these agrarian communities, Nigeria inclusive, forest foods are essential dietary supplements especially during lean agricultural production periods or times of emergency. The Nigerian Study/Action Team (NEST, 1991) submitted that leaves, fruits, nuts and oils obtained from wild plants have provided food for humans, livestock and wildlife in many parts of the country. Latiff et al. (2002) reported that forest resources directly contributed up to $80 \%$ of the livelihoods of the people in that country living in extreme poverty.

Alfezia africana, Parkia biglobosa, Prosopis africana and many other species are most of the fruit and food trees suitable for outlying farms in the derived savannah fall into the categories of semi-wild and protected species in cultivated farmland. Borassus aethiopum and Adansonia digitata provide food, income and employment to the people (Tee and Popoola, 2007; Tella et al., 2008; Tee and Verinumbe, 2007). All these species are important sources of food (Okafor, 1980) ranging from staple items like moulded fruit pulp and condiments of seed of $P$. biglobosa. Brown material obtained from $P$. 
biglobosa and F. polite, Leafy vegetables of Vitex doniana, edible fruits of Butyrospermum paradoxum and Borassus aethiopium and many others. Wild fruits and leaves from trees and shrubs provide good nutritious supplements to diet such as protein, vitamins and roughages and also medicinal value at certain times of their growing period. They provide protein, energy, starch, vitamins and essential minerals to human diet. Above all, they also provide income and employment opportunities to rural and urban households (Tee et. al. 2009). Several crops were reported to perform better around and under the shade of $P$. biglobosa (Okafor 1980). Parkia biglobosa tree is important in North-central Nigeria along with other species like Prosopis africana, Acacia Species, Borassus aethiopum, Adansonia digitata and Tamirandus indica (Verinumbe, 1991).

The roots, barks, leaves, stems, flowers, fruits and seeds of $P$. biglobosa are all used medicinally to treat a range of ailments including diarrhoea, ulcers, pneumonia, burns, coughs, jaundice etc (Sacande and Clethero, 2007). The pulp contains higher cellulose and sucrose but less ascorbic acid than the cotyledons. The pulp also contains simple sugars except maltose (Alabi et.al.2005). The seeds of $P$. biglobosa on fermentation are used in cooking stew and soup. The sweet yellow pulp contains $60 \%$ sugar when ripe and the seeds contain $30 \%$ protein as well as vitamins and minerals (Sacande and Clethero, 2007). The fruit pods are used to produce an insecticide powder for treating crops.

\section{MATERIALS AND METHODS}

Fruit and seed characteristics were studied among twenty six (26) Parkia biglobosa (Jacq.) G. Don. tree population in the permanent site of the University of Ilorin campus, Nigeria. Three bunches were collected from each plant (tree) sample and were used for the fruit and seed characteristics studies where pod number per bunch, pod length, pod breadth, pulp weight per bunch, seed weight per bunch, weight of 100 seeds per plant sample, seed colour, seed texture, seed size and shape were taken. The pulp and seeds were removed manually from dry brown indehiscent pods of matured fruit by using hand to break the pods along the sutures (Shelling); depulping was done by manual washing in water to remove the seeds from the pulp covering them. Seeds were then sun dried, weighed, counted and packed after which the seed colour, texture, shape and size were determined. Data collected were subjected to statistical analysis using analysis of variance (ANOVA) and means were separated using New Duncan multiple range test (DMRT).

\section{RESULT AND DISCUSSION}

The results of fruit and seed characteristics of Parkia biglobosa populations are presented in tables $1-3$. These results show an amazing significant differences at $(P<0.05)$ among the population of Parkia biglobosa plants studied.

Table 1 revealed plant number twenty one (21) to have the highest number of pod per bunch (15.00) while the lowest was recorded in plant fifteen (15) with 6 pods per bunch. Plants 1, 2, 22 and 25 have approximately the same number of pods per bunch ranging from $13.00-$ 13.67, while plants 10, 12, 23 and 24 had $10.00-10.67$. The longest pod length was recorded in plant 19 and the shortest in plant 3 with $27.13 \mathrm{~cm}$ and $15.24 \mathrm{~cm}$ respectively. The pod breadth at apex, middle and base varies among various Parkia biglobosa plant population with the widest apex observed in plant $6(1.53 \mathrm{~cm})$ and narrowest in plants 11 and $18(0.91 \mathrm{~cm})$. Widest pod breadth at the middle was found in plant $23(2.53 \mathrm{~cm})$ and its narrowest counterpart in plant $2(1.33 \mathrm{~cm})$. Plants 1,6 , $8,12,13$ all fall in the range of $2.09 \mathrm{~cm}-2.77 \mathrm{~cm}$ in their pod breadth at the middle. The pod breadth size at the base was observed in plant 8 to be the widest $(1.69 \mathrm{~cm})$ and the narrowest in plant $3(0.29 \mathrm{~cm})$. Every other plant falls within the range of $1.14-1.53 \mathrm{~cm}$. Some of the Parkia biglobosa population (plants 1, 6, 8, 12, 13 and 23) fit in to the description of the millennium seed bank project Kew which reported Parkia biglobosa pod to be 2-3cm wide (Sacande and Clethero, 2007). The pulp and seed weight also varied in the population with $102.33 \mathrm{~g}$ as the highest value observed in plant 22 and plant 18 had the lowest $(26.67 \mathrm{~g})$. Highest value of the pulp weight was observed in plant 22. Plants 22 and 18 showed highest and lowest values respectively in pulp + seed weight and pulp weight alone (Table1).

Plant 23 has the largest number of expected seed per pod (i.e no of seed positions observed in each pod before de-pulping of fruit by mere feeling with hands at the depressions formed on the pods) with 21.33 while the smallest number was observed in plant 16 with 8.78 (Table 2). The number of expected seed/pod ranges from $8.98-21.33$ in all the population with plants 8,18 and 24 ranging from 14.22 - 14.44 having approximately the same number of expected seed/pod. The number of seed/bunch was observed to be highest in plant $22(225.00)$ and smallest in plant 15 (64.89). The number of seed/bunch ranges from 64.33 - 225.00 throughout the population. Other plants with low seed weight value are 4, 14, 15 and 16. 
Table 1: Fruit characteristics among selected Parkia biglobosa population

\begin{tabular}{|c|c|c|c|c|c|c|c|}
\hline \multirow[t]{2}{*}{ Plant no } & \multirow[t]{2}{*}{$\begin{array}{l}\text { Mean pod } \\
\text { no/bunch }\end{array}$} & \multirow[t]{2}{*}{$\begin{array}{l}\text { Mean pod } \\
\text { length }(\mathrm{cm})\end{array}$} & \multicolumn{3}{|c|}{ Mean pod breadth(cm) } & \multirow[t]{2}{*}{$\begin{array}{l}\text { Pulp+seed } \\
\text { wt(g) }\end{array}$} & \multirow[t]{2}{*}{ Pulp wt(g) } \\
\hline & & & Apex & Middle & Base & & \\
\hline 1 & $13.33^{a-c}$ & $22.94^{a-c}$ & $1.27^{\mathrm{a}-\mathrm{d}}$ & $2.19^{a-c}$ & $1.44^{\mathrm{a}-\mathrm{d}}$ & $87.33^{a-d}$ & $53.33^{a-c}$ \\
\hline 2 & $13.67^{\mathrm{ab}}$ & $22.33^{a-d}$ & $1.03^{\mathrm{b}-\mathrm{d}}$ & $1.33^{\mathrm{g}}$ & $1.14^{\mathrm{c}-\mathrm{e}}$ & $84.67^{a-d}$ & $52.00^{a-c}$ \\
\hline 3 & $6.67^{\mathrm{cd}}$ & $15.24^{d}$ & $0.96^{\mathrm{cd}}$ & $1.34^{\mathrm{fg}}$ & $0.92^{\mathrm{e}}$ & $69.67^{\mathrm{a}-\mathrm{e}}$ & $34.33^{a-d}$ \\
\hline 4 & $7.00^{\mathrm{b}-\mathrm{d}}$ & $18.06^{b-d}$ & $1.07^{\mathrm{b}-\mathrm{d}}$ & $1.73^{\mathrm{c}-\mathrm{g}}$ & $1.38^{a-d}$ & $34.67^{\text {ef }}$ & $21.67^{\mathrm{cd}}$ \\
\hline 5 & $8.00^{b-d}$ & $17.95^{\mathrm{cd}}$ & $1.00^{b-d}$ & $1.73^{\mathrm{c}-\mathrm{g}}$ & $1.20^{\mathrm{c}-\mathrm{e}}$ & $49.33^{c-f}$ & $24.67^{b-d}$ \\
\hline 6 & $11.33^{a-d}$ & $22.92^{a-c}$ & $1.53^{\mathrm{a}}$ & $2.27^{\mathrm{ab}}$ & $1.53^{\mathrm{a}-\mathrm{c}}$ & $89.67^{\mathrm{abc}}$ & $57.67^{\mathrm{ab}}$ \\
\hline 7 & $8.00^{b-d}$ & $21.18^{a-d}$ & $1.39^{\mathrm{a}-\mathrm{c}}$ & $1.98^{\mathrm{b}-\mathrm{e}}$ & $1.48^{\mathrm{a}-\mathrm{c}}$ & $55.00^{c-f}$ & $36.00^{a-d}$ \\
\hline 8 & $7.33^{b-d}$ & $20.34^{a-d}$ & $1.31^{a-d}$ & $2.12^{\mathrm{a}-\mathrm{c}}$ & $1.69^{\mathrm{a}}$ & $41.00^{\mathrm{ef}}$ & $22.67^{\mathrm{cd}}$ \\
\hline 9 & $7.00^{b-d}$ & $18.99^{b-d}$ & $1.35^{a-d}$ & $1.84^{b-f}$ & $1.42^{\mathrm{a}-\mathrm{d}}$ & $52.67^{c-f}$ & $30.00^{a-d}$ \\
\hline 10 & $10.00^{a-d}$ & $22.13^{a-d}$ & $1.05^{b-d}$ & $1.55^{\mathrm{eg}}$ & $1.36^{a-d}$ & $88.33^{\mathrm{abc}}$ & $52.67^{a-c}$ \\
\hline 11 & $9.33^{a-d}$ & $18.96^{b-d}$ & $0.91^{d}$ & $1.70^{c-g}$ & $1.21^{\mathrm{b}-\mathrm{e}}$ & $63.67^{a-f}$ & $38.33^{a-d}$ \\
\hline 12 & $10.33^{a-d}$ & $17.95^{\mathrm{cd}}$ & $1.42^{\mathrm{ab}}$ & $2.00^{b-e}$ & $1.23^{b-e}$ & $54.67^{c-f}$ & $32.00^{a-d}$ \\
\hline 13 & $7.00^{b-d}$ & $21.88^{a-d}$ & $1.36^{a-d}$ & $2.09^{a-d}$ & $1.38^{a-d}$ & $46.33^{d-f}$ & $28.33^{a-d}$ \\
\hline 14 & $9.00^{a-d}$ & $23.37^{a-c}$ & $1.18^{a-d}$ & $1.89^{\mathrm{b}-\mathrm{e}}$ & $1.23^{b-e}$ & $49.67^{c-f}$ & $34.00^{a-d}$ \\
\hline 15 & $6.00^{d}$ & $25.38^{\mathrm{ab}}$ & $1.09^{b-d}$ & $1.80^{b-g}$ & $1.26^{b-e}$ & $38.00^{\text {ef }}$ & $22.00^{\mathrm{cd}}$ \\
\hline 16 & $8.67^{a-d}$ & $17.09^{\text {cd }}$ & $1.14^{a-d}$ & $1.60^{d-g}$ & $1.21^{b-e}$ & $53.00^{c-f}$ & $39.33^{a-d}$ \\
\hline 17 & $11.67^{\mathrm{a}-\mathrm{d}}$ & $20.87^{a-d}$ & $1.07^{b-d}$ & $1.79^{b-g}$ & $1.49^{a-c}$ & $84.00^{a-d}$ & $53.33^{a-c}$ \\
\hline 18 & $6.67^{\mathrm{cd}}$ & $21.11^{a-d}$ & $0.91^{d}$ & $1.56^{\mathrm{eg}}$ & $1.33^{c-e}$ & $26.67^{f}$ & $15.67^{d}$ \\
\hline 19 & $7.67^{b-d}$ & $27.13^{\mathrm{a}}$ & $1.12^{a-d}$ & $1.98^{\mathrm{b}-\mathrm{g}}$ & $1.21^{\mathrm{b}-\mathrm{e}}$ & $67.00^{a-f}$ & $45.00^{a-d}$ \\
\hline 20 & $9.33^{a-d}$ & $21.27^{\mathrm{a}-\mathrm{d}}$ & $1.05^{b-d}$ & $1.81^{b-g}$ & $1.05^{\mathrm{de}}$ & $60.33^{b-f}$ & $37.33^{a-d}$ \\
\hline 21 & $15.00^{\mathrm{a}}$ & $20.01^{a-d}$ & $1.07^{b-d}$ & $1.78^{b-g}$ & $1.31^{a-d}$ & $70.00^{\mathrm{a}-\mathrm{e}}$ & $40.00^{a-d}$ \\
\hline 22 & $13.00^{a-c}$ & $22.43^{a-d}$ & $0.95^{\mathrm{cd}}$ & $1.72^{\mathrm{c}-\mathrm{g}}$ & $1.21^{\mathrm{b}-\mathrm{e}}$ & $102.33^{\mathrm{a}}$ & $59.67^{a}$ \\
\hline 23 & $10.33^{a-d}$ & $26.75^{a}$ & $1.16^{a-d}$ & $2.53^{a}$ & $1.60^{\mathrm{ab}}$ & $97.00^{\mathrm{ab}}$ & $53.33^{a-c}$ \\
\hline 24 & $10.67^{a-d}$ & $21.35^{a-d}$ & $1.08^{b-d}$ & $1.88^{\mathrm{b}-\mathrm{e}}$ & $1.20^{c-e}$ & $52.67^{c-f}$ & $26.33^{a-d}$ \\
\hline 25 & $13.00^{a-c}$ & $17.72^{\text {cd }}$ & $1.14^{a-d}$ & $1.74^{\mathrm{c}-\mathrm{g}}$ & $1.14^{c-e}$ & $62.67^{a-f}$ & $39.33^{a-d}$ \\
\hline 26 & $9.33^{a-d}$ & $20.09^{a-d}$ & $1.03^{b-d}$ & $1.70^{\mathrm{c}-\mathrm{g}}$ & $1.16^{\mathrm{c}-\mathrm{e}}$ & $69.67^{a-e}$ & $47.67^{a-d}$ \\
\hline
\end{tabular}

Values with the same letter(s) along the same columns are not significantly different at $(p=0.05)$ 


\begin{tabular}{|l|l|l|l|}
\hline Plant number & Expected seed no/pod & No of seed/bunch & Seed wt/bunch $(\mathrm{g})$ \\
\hline 1 & $16.56^{\mathrm{a}-\mathrm{c}}$ & $154.33^{\mathrm{b}-\mathrm{d}}$ & $34.00^{\mathrm{a}-\mathrm{d}}$ \\
\hline 2 & $17.44^{\mathrm{ab}}$ & $159.33^{\mathrm{a}-\mathrm{d}}$ & $32.67^{\mathrm{a}-\mathrm{d}}$ \\
\hline 3 & $13.33^{\mathrm{bc}}$ & $168.33^{\mathrm{a}-\mathrm{c}}$ & $35.33^{\mathrm{a}-\mathrm{c}}$ \\
\hline 4 & $12.78^{\mathrm{bc}}$ & $64.33^{f}$ & $13.00^{\mathrm{g}}$ \\
\hline 5 & $16.00^{\mathrm{a}-\mathrm{c}}$ & $120.67^{\mathrm{b}-\mathrm{f}}$ & $24.67^{\mathrm{b}-\mathrm{g}}$ \\
\hline 6 & $16.89^{\mathrm{ab}}$ & $132.33^{\mathrm{b}-\mathrm{f}}$ & $32.00^{\mathrm{a}-\mathrm{e}}$ \\
\hline 7 & $15.00^{\mathrm{a}-\mathrm{c}}$ & $101.33^{\mathrm{c}-\mathrm{f}}$ & $19.00^{\mathrm{c}-\mathrm{g}}$ \\
\hline 8 & $14.22^{\mathrm{a}-\mathrm{c}}$ & $81.33^{\mathrm{ef}}$ & $18.33^{\mathrm{d}-\mathrm{g}}$ \\
\hline 9 & $15.22^{\mathrm{a}-\mathrm{c}}$ & $80.33^{\mathrm{f}}$ & $22.67^{\mathrm{b}-\mathrm{g}}$ \\
\hline 10 & $18.55^{\mathrm{ab}}$ & $128.33^{\mathrm{b}-\mathrm{f}}$ & $35.67^{\mathrm{ab}}$ \\
\hline 11 & $15.89^{\mathrm{a}-\mathrm{c}}$ & $134.00^{\mathrm{b}-\mathrm{f}}$ & $25.33^{\mathrm{b}-\mathrm{g}}$ \\
\hline 12 & $13.11^{\mathrm{bc}}$ & $102.33^{\mathrm{c} f}$ & $22.67^{\mathrm{b}-\mathrm{g}}$ \\
\hline 13 & $17.45^{\mathrm{ab}}$ & $77.00^{\mathrm{ef}}$ & $18.00^{\mathrm{d}-\mathrm{g}}$ \\
\hline 14 & $8.89^{\mathrm{c}}$ & $71.67^{f}$ & $15.67^{\mathrm{e}-\mathrm{g}}$ \\
\hline 15 & $17.89^{\mathrm{ab}}$ & $64.89^{f}$ & $16.00^{\mathrm{fg}}$ \\
\hline 16 & $8.78^{\mathrm{c}}$ & $81.00 \mathrm{e}^{\mathrm{f}}$ & $13.67^{\mathrm{fg}}$ \\
\hline 17 & $19.89^{\mathrm{ab}}$ & $190.33^{\mathrm{a}}$ & $30.67^{\mathrm{a}-\mathrm{e}}$ \\
\hline 18 & $14.44^{\mathrm{a}-\mathrm{c}}$ & $66.00^{f}$ & $11.00^{\mathrm{g}}$ \\
\hline 19 & $15.22^{\mathrm{a}-\mathrm{c}}$ & $95.00^{\mathrm{d}-\mathrm{f}}$ & $22.00^{\mathrm{b}-\mathrm{g}}$ \\
\hline 20 & $16.11^{\mathrm{a}-\mathrm{c}}$ & $114.67^{\mathrm{c}-\mathrm{f}}$ & $23.00^{\mathrm{b}-\mathrm{g}}$ \\
\hline 21 & $15.45^{\mathrm{a}-\mathrm{c}}$ & $145.00^{\mathrm{b}-\mathrm{e}}$ & $30.00^{\mathrm{a}-\mathrm{f}}$ \\
\hline 22 & $19.67^{\mathrm{ab}}$ & $225.00^{\mathrm{a}}$ & $42.67^{\mathrm{a}}$ \\
\hline 23 & $21.33^{\mathrm{a}}$ & $160.00^{\mathrm{a}-\mathrm{d}}$ & $43.67^{\mathrm{a}}$ \\
\hline 24 & $14.33^{\mathrm{a}-\mathrm{c}}$ & $112.00^{\mathrm{c}-\mathrm{f}}$ & $26.33^{\mathrm{b}-\mathrm{g}}$ \\
\hline 25 & $18.00^{\mathrm{ab}}$ & $119.67^{\mathrm{c}-\mathrm{f}}$ & $23.33^{\mathrm{b}-\mathrm{g}}$ \\
\hline 26 & $17.00^{\mathrm{ab}}$ & $118.00^{\mathrm{c}-\mathrm{f}}$ & $20.00^{\mathrm{b}-\mathrm{g}}$ \\
\hline
\end{tabular}

Values with the same letter(s) along the same column are not significantly different at $(p=0.05)$. 
Table3: Qualitative characteristics of seeds among selected Parkia biglobosa population

\begin{tabular}{|l|l|l|l|l|}
\hline Plant number & Seed colour & Shape & Size & Textture \\
\hline 1 & Db & Fo & Bg & Smo \\
\hline 2 & Brown & Rov & Sm & Smo \\
\hline 3 & Var. Brown & Fo & Bg & Smo \\
\hline 4 & Choco brown & Fo & Bg & Smo \\
\hline 5 & Db & Rov & Sm & Smo \\
\hline 6 & Db & Fo & Bg & Smo \\
\hline 7 & Choco brown & Rov & Md & Smo \\
\hline 8 & Db & Fo & Bg & Smo \\
\hline 9 & Db & Fo & Md & Smo \\
\hline 10 & Db & Fo & Md & Smo \\
\hline 11 & Black & Rov & Md & Smo \\
\hline 12 & Choco brown & Fo & Bg & Smo \\
\hline 13 & Var. Brown & Fo & Bg & Smo \\
\hline 14 & Db & Fo & Md & Smo \\
\hline 15 & Db & Fo & Md & Smo \\
\hline 16 & Choco brown & Rov & Sm & Smo \\
\hline 17 & Black & Fo & Sm & Smo \\
\hline 18 & Db & Rov & Md & Smo \\
\hline 19 & Var. Brown & Fo & Bg & Smo \\
\hline 20 & Choco brown & Oval & Md & Wrk \\
\hline 21 & Db & Rov & Md & Smo \\
\hline 22 & Db & Rov & Md & Smo \\
\hline 23 & Choco brown & Fo & Bg & Smo \\
\hline 24 & Db & Fo & Md & Smo \\
\hline 25 & Var. Brown & Rov & Md & Smo \\
\hline 26 & Db & Rov & Sm & Smo \\
\hline Va brow & Do & & \\
\hline
\end{tabular}

Var brown=Variegated brown

Choco brown=Chocolate brown

$\mathrm{Bg}=$ Big, Md=Medium, Sm= Small,
$\mathrm{Db}=$ Dark brown

Fo=Flat oval, Wrk=Wrinkle, Rov= Round oval Smo=Smooth

pods) are also similar to the report of Staples and For the Qualitative characteristics of seeds among the Elevitch (2009) on the description of Samanea saman Parkia biglobosa population, plant 20 was observed to (rain tree). Seed characteristics of some Parkia biglobosa have a wrinkled seed coat while others have smooth population also agree with the characteristics of Garden seed coat. 15 plants of the selected Parkia biglobosa pea as reported by Akhter et, al, (2009) in terms of seed population have flat oval seed shape and others having colour, seed shape and texture of the seed coat and the shapes between round oval and oval. Their sizes fall description of Sacande and Clethero (2007) on the among big (plants 1, 3, 4, 6, 8, 12, 13, 19 and 23), millennium seed bank project kew.

medium (plants $7,9,10,11,14,15,18,20,21,22,24$

and 25) and small (plants 2, 5, 16, 17 and 26). The seeds

of plants $1,5,6,8,9,10,14,15,18,21,24$ and 26 are The population of Parkia biglobosa studied revealed an dark brown in colour, two plants have pure black and the amazing character display that cuts across the number of others have brown related seed coat colours (Table3). pods per bunch, number of seeds per pod, number of The characteristics of the fruit and seed of Parkia seeds per bunch, seed colour, seed weight, and fruit pulp biglobosa population studied (seed brown-blackish weight. Seed colour was majorly within brown and black colour, ovoid-related, smooth and varied sizes within the derivatives with smooth seed coat texture. 


\section{REFERENCES}

Akhter, N., Rahman, M.M., Hasanuzzaman, M. and Nahar, K., (2009). Physiological Response of Garden Pea (Pisum sativum L.) Growth under Different Light Environment. Botany Research International 2 (4) 304-309.

Alabi, D.A., Akinsulire, O. R. And Sanyaolu, M.A (2005). Qualitative determination of chemical and nutritional composition of Parkia biglobosa (Jacq.) Benth. African Journal of Biotechnology Vol. 4 (8), pp. 812-815. Forest Product in Pakistan. Ethno-Botany Project. WWF-P, Peshawar, Pakistan.

Joshi, A.R and Joshi, K. (2009). Plant Diversity and Ethnobotanical notes on tree species of Syabru Village, Langtang National park, Nepal. Ethno botanical leaflets 13: 651-64.

Latif, A., Z.K. Shinwari and S. Begum, (2002). Potentials and Market status of Mushrooms as Non-timber Nontimber Forest Production in Pakistan. Ethno-Botany Project. WWF-P, Peshawar, Pakistan.

NEST, (1991). Nigeria's threatened environment: a National profile.

Okafor, J. C., (1980). Edible Indigenous Woody Plants in the Rural Economy of the Nigerian Forest Zone. Forest Ecology and Management Vol 3: 45-55.

Popoola, L. and H. Maishanu, (1995). Socio-economic values of some potential farm forestry species in
Sokoto State. Proceeding of the 24th Annual Conference of the Forestry Association of Nigeria. Kaduna. Oduwaiye, E.A., (Edn.), pp: 109-119.

Sacande, M. and Clethero, C, (2007). Parkia biglobosa (Jacq.) G. Don. Millennium Seed Bank Project Kew. Seed Leaflet No 124.

Tee, N.T. and I. Verinumbe, (2007). Utility dynamic and prioritization of Borassus aethiopum (Mart) in Northeastern Nigeria. J. Agri. Res. Policies, 3: 87-93.

Tee, N.T. and L. Popoola, (2007). The role of Borassus aethiopum (Mart) on livelihood sustainability, the North-eastern Nigeria Experience. Discovery and Innovation, 19: 230-237.

Tella, I.O., M.O. Tella and A.Y. Buba, (2008). Utilization and Commercialization of two MPTS (Borassus aethiopum and Adansonia digitata in Some semiarid Communities, In: J.C. Onyekwelu, V.A.J. Adekunle and D.O. Oke (Edn.) Proceedings of the First National Conference of the Forest and Forestry Products Society. 16th -18th April, At the Federal University of Technol. Akure, pp: 140-146.

Verinumbe, I., (1991). Agroforestry development in northeastern Nigeria. Forestry Ecology and Management. Elsvier Publishers B.U. Amsterdam, 45: 309-317. 